\title{
Study of Active Substances Involved in Skin Dysfunction Induced by Crowding Stress. I. Effect of Crowding and Isolation on Some Physiological Variables, Skin Function and Skin Blood Perfusion in Hairless Mice
}

\author{
Hitoshi Ishida, ${ }^{*, a}$ Katsukuni Mitsui, ${ }^{a}$ Haruo Nukaya, ${ }^{a}$ Katsuo Matsumoto, ${ }^{b}$ and Kuniro Tsus ${ }^{a}$ \\ ${ }^{a}$ School of Pharmaceutical Science, University of Shizuoka; 52-1 Yada, Shizuoka 422-8526, Japan: and ${ }^{b}$ POLA Chemical \\ Industries, Inc.; 560 Kashio-cho, Totsuka-ku, Yokohama 244-0812, Japan. \\ Received August 15, 2002; accepted November 25, 2002
}

The effects of five levels of population density on various organs, the neuroendocrine system, skin function, skin blood perfusion, and blood parameters were studied in the hairless mouse. Skin barrier recovery was evaluated by measuring transepidermal water loss after tape stripping. Blood perfusion was measured by means of a laser Doppler imaging technique. The effect of a parasympathetic nerve stimulator, carpronium chloride, on skin function in the crowded animal model was also examined. A $7 \mathrm{~d}$ crowding $(10,15,20 \mathrm{mice} /$ cage $)$ significantly increased the levels of corticosterone, catecholamines (norepinephrine, epinephrine and dopamine), glucose and serum lactate dehydrogenase activity in circulating blood, induced atrophy of kidney, ovary and thymus and hypertrophy of adrenal glands, and decreased body weight gain in comparison with the control (5 mice/cage). Crowding also increased epidermal thickness and epidermal proliferative activity, and decreased corneocyte size, rate of barrier recovery and skin blood perfusion. Most of these changes became more marked with increasing population density and/or longer exposure to a crowded environment. Isolation (1 mouse/cage) increased the level of norepinephrine and rate of skin blood perfusion, and significantly delayed barrier recovery. Repeated topical applications of carpronium chloride for $7 \mathbf{d}$ improved the changes in skin blood perfusion, barrier recovery, kidney and ovary, and epidermal morphology induced by crowding. The crowded animal model could be useful for quantifying objectively the influence of crowded environment-induced stress on cutaneous function and blood perfusion.

Key words crowded environment stress; barrier recovery; skin blood perfusion; corticosterone; catecholamine; adrenal gland

Human skin functions not only as a barrier to retain the internal components and to protect internal organs from external stimulation or invasion, but also as a sensory organ to maintain homeostasis. In addition, it plays important roles in processes such as thermoregulation, antibody formation, vitamin D formation, lipid secretion, respiration, pigmentation and perception. ${ }^{1-6)}$

Stress disturbs the homeostasis, and may induce various disorders. For example, various kinds of physiological and psychological stress influence the hypothalamic-pituitaryadrenocortical axis, the hypothalamic-pituitary-gonadal axis, sympatho-adrenomedullary system and sympathetic nervous system, leading to changes in a number of organs. Stress has been implicated in hypertension, arteriosclerosis, diabetes mellitus, and other diseases in clinical and epidemiological studies. ${ }^{7)}$ Skin function should also be influenced by stress, because it is primarily regulated by the autonomic nervous system and the endocrine system. This idea is supported by clinical reports showing that some skin disorders, including psoriasis and atopic dermatitis, are exacerbated by anxiety. ${ }^{8)}$ In addition, recent cutaneous biological studies have revealed that immobilization stress and/or overcrowding stress induced a decrease in lipogenesis in sebaceous glands, delay of skin barrier recovery and disruption of the skin barrier in rats, Syrian hamsters, and/or BALB/c mice. ${ }^{9-11)}$ Barrier function and water retention are important cutaneous functions to maintain homeostasis. However, the relationship between stressful stimuli and skin dysfunction has not been established yet.

Psychological stress activates the sympathetic nervous sys- tem, resulting in increases in the levels of glucocorticoids, catecholamines and angiotensin II in the circulating blood. Excess of glucocorticoid and angiotensin II can elevate blood pressure and excess of catecholamine increases cardiac output and peripheral resistance. Thus, stress induces acute hypertonic and chronic circulatory disorders. Hypertension causes hematogeneous disorder in the microvasculature. Therefore, concomitant reduced blood supply may contribute to peripheral ischemia. It is also suggested that mental stress induces transient endothelial dysfunction in humans. ${ }^{12)}$ Indeed, it is well recognized that psychological stress elevates blood pressure and that long-term stress causes dysfunction of the skin and various organs, such as ovary, kidney, thymus and adrenal glands.

Recently, the laser Doppler perfusion-imaging technique has made it possible to map accurately changes of blood perfusion over a large area with good time resolution, and this method has been used to measure microcirculatory changes of the skin, mucosa, kidney and eye. ${ }^{13,14)}$ It has also been used for detecting abnormal blood flow in pathologically changed skin. ${ }^{15)}$

In this study, we have examined the relationship between blood perfusion and skin dysfunction mediated by catecholamines in animals exposed to a crowded environment. This approach has been used in the fields of neurophysiology, neuropathology and neuropharmacology to provide a model of psychological stress. ${ }^{16-18)}$ In our study, we used hairless mice as an experimental model to examine the effects of isolation and crowding on body weight gain, several organs including those related to the immune system, skin blood flow, 
epidermal morphology, secretion of stress hormones, and blood parameters. In addition, the effect of topical carpronium chloride in this crowding-induced stress model was examined.

\section{MATERIALS AND METHODS}

Animals and Materials Female hairless mice (HOS:HR-1, 6 weeks of age) were purchased from Japan SLC (Hamamatsu, Japan). They were housed in an environmentally controlled laboratory in a $12 \mathrm{~h}$ light/ $12 \mathrm{~h}$ dark environment, with the light on at 8:00. Temperature was maintained at $23.0 \pm 1.0^{\circ} \mathrm{C}$ and humidity at $55.0 \pm 5.0 \%$, and food and water were available ad libitum. Before being subjected to stress experiments, the animals were housed in groups of five in plastic cages $(225 \times 338 \times 140 \mathrm{~mm})$ for 6 weeks.

Carpronium chloride ((3-carboxypropyl)trimethylammonium chloride methyl ester) was purchased from Daiichi Pharmaceutical Co., Ltd. (Tokyo, Japan).

Rat anti-BrdU monoclonal antibody was purchased from Harlan Sera Lab, and goat anti-rat IgG monoclonal antibody $(\mathrm{H}+\mathrm{L}$ chain-specific, biotin-conjugated), streptavidin (horseradish peroxidase-conjugated) and rat IgG2a isotypematched control from Southern Biotechnology Associates. These antibodies and the reagent were used in this study after dilution $(1: 100$ or $1: 300)$.

Isolated and Crowded Environment-Induced Stress Exposure, Blood Collection and Test Compound Administration The animals (12 weeks of age) weighing $27.0 \pm 0.8$ $\mathrm{g}$ were divided into five experimental groups: Group Isolating (isolated mice, 1 per cage); Group Control (untreated control mice, 5 per cage); Group Crowding-1, 2 and 3 (crowded mice, 10, 15 and 20 per cage, respectively). One, five, ten, fifteen and twenty mice were, respectively, housed in new cages throughout the experimental period for 1 to 13 $\mathrm{d}$ (day -6 to day 5), as shown in Fig. 1. Carpronium chloride in ethanol was applied topically on a restricted area of the back for $8 \mathrm{~d}$ (day -7 to day 0 ) prior to tape stripping. Ethanol alone was used as the control. Food consumption per cage in each group and body weight gain of each animal were measured every day from day -7 to day 0 .

During stress experiments, blood samples for hormone level measurement and hemocyte analysis were collected after decapitation. At the same time, heart, kidney, liver, ovary, thymus and adrenal glands of each animal were immediately removed and weighed. In other experiments, immediately after stress was relieved, the animals were anesthetized with sodium pentobarbital $(50 \mathrm{mg} / \mathrm{kg}$, Nembutal) (Tokyo Chemical Industries, Co., Ltd., Tokyo). Then blood samples were withdrawn from the jugular vein into a plastic syringe to examine the biochemical profile of the serum.

This study was approved by the Animal Research Committee of the University of Shizuoka in accordance with the NRC Guide.

Corticosterone and Catecholamine Measurement Each blood sample was mixed with heparin for plasma preparation or allowed to stand at room temperature for 30 min for serum collection, and then centrifuged at $1000 \boldsymbol{g}$ for $15 \mathrm{~min}$. Serum corticosterone level was determined by radioimmunoassay (RIA) measurement, using commercial RIA kits (Coat-A-Count ${ }^{\circledR}$ TKRC1, Diagnostic Products Corpora-

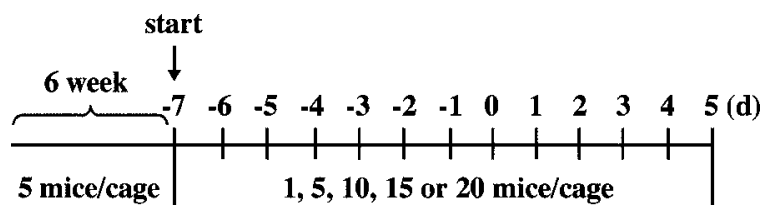

Fig. 1. Stress Exposure Procedures

Mice were maintained at 5 mice/cage before stress exposure. They were divided into five experimental groups: isolated mice (Isolating; 1 mouse/cage), untreated mice (Control; 5 mice/cage) and crowded mice (Crowding-1, 2 and 3; 10, 15 and 20 mice/cage). Mice were stressed by isolating or crowding throughout the experiment, and were subjected to measurements.

tion, U.S.A.). ${ }^{19,20)}$ Plasma norepinephrine, epinephrine and dopamine levels were analyzed by HPLC with an Eicompak CA-5ODS column $(4.6 \times 150 \mathrm{~mm}$, Eicom Co., Ltd., Japan) and an electrochemical detector EC-8020 (Tosoh Co., Ltd., Japan) after purification with Boric Acid Gel (Aldrich, U.S.A.), respectively. ${ }^{21)}$ The mobile phase was as follows: $0.1 \mathrm{~m}$ sodium citrate buffer ( $\mathrm{pH}$ 5.0)-acetonitrile (94:6) $(\mathrm{v} / \mathrm{v})$, containing $6.0 \mathrm{~mm}$ sodium 1-octanesulfonate and 2.0 mm disodium EDTA. The flow rate was $1.0 \mathrm{ml} / \mathrm{min}$, at room temperature.

Hemocyte Analysis The counts of total white blood cells, red blood cells and platelets and hematocrit in the blood were measured with an automatic counter (Sysmex K1000, Toa Medical Electronics, Kobe, Japan).

Biochemical Profile of Serum Blood samples withdrawn from the jugular vein were centrifuged at $1000 \boldsymbol{g}$ for $15 \mathrm{~min}$ to obtain serum, after having been left for $30 \mathrm{~min}$ at room temperature. Total lactate dehydrogenase (LDH) and alkaline phosphatase (ALP) activity and glucose, total cholesterol, high-density lipoprotein (HDL)-cholesterol and triglyceride concentrations in this serum were measured with commercial kits, LDH CII, ALP K, Glucose C, Cholesterol E, HDL-cholesterol E and Triglyceride G TEST Wako (Wako Pure Chemical Industries, Co., Ltd., Osaka), respectively. LDH isozyme electrophoresis was carried out essentially according to Schultze $e t \mathrm{al}^{22)}$ Prior to electrophoresis, samples were diluted to approximately $400-600 \mathrm{IU} / 1$ with phosphate-buffered saline (PBS). Isozymes were then separated on agarose gel (Lactate Dehydrogenase Isozyme Test Wako Kit, Wako Pure Chemical Industries, Co., Ltd., Osaka). Samples were electrophoresed for $20 \mathrm{~min}$ at $100 \mathrm{~V}$ (Power Station AE-8450, ATTO Corp., Tokyo). After electrophoresis, the isozymes were visualized by a specific colorimetric reaction with the Lactate Dehydrogenase Isozyme Test Wako Kit. Gels were fixed by immersion in EtOH$\mathrm{H}_{2} \mathrm{O}-\mathrm{AcOH}(14: 5: 1)$ and scanned using a densitometer (Densitograph AE 6905, ATTO Corp., Tokyo). Control LDH isozymes, $\mathrm{LDH}_{1}, \mathrm{LDH}_{2}, \mathrm{LDH}_{3}, \mathrm{LDH}_{4}$ and $\mathrm{LDH}_{5}$, were prepared from thymus of the hairless mouse. LDH activity of each isozyme was determined by multiplying the total LDH activity of each sample by the relative fraction of each isozyme determined by densitometry.

Skin Lipids According the method of Dikstein et al. ${ }^{23)}$ lipid level on a back skin site was measured with a photometric instrument, SKICOS 301 (Amique Group Co., Ltd., Japan), immediately after the animals had been released from stress. After calculation of the increase in transparency from measurements of the rough surfaces of tapes that were unused and that had been in contact with skin, the values were 
transformed into equivalent amounts of lipid present on a square centimeter of the test area.

Blood Perfusion in Back Skin With reference to the method of Bjarnason et al., ${ }^{24)}$ blood perfusion of the back skin was evaluated with a Laser Doppler Perfusion Imager (LDPI) PIM II (Lisca Development AB, Linköping, Sweden) immediately after the animal had been fixed in a prone position. A computer-controlled optical scanner directs a lowpower $\mathrm{He}-\mathrm{Ne}$ laser beam at the tissue. The back skin is scanned by moving the laser beam step-by-step in a rectangular pattern over the skin surface, with a reading distance of $15 \mathrm{~cm}$ between the laser head aperture and the center of the test area. The angle between the LDPI laser beam and the skin surface to be measured was set as close to $90^{\circ}$ as possible. The reading areas were $20 \times 20$ points, which corresponded to an area of $25 \times 25 \mathrm{~mm}$. High resolution, a background threshold of $6.2 \mathrm{~V}$ and an amplification factor of 1.0 were selected. The perfusion value scale ranged from 0.00 to $10.00 \mathrm{~V}$ (arbitrary units). Immediately before the experiment on day -7 and on days -4 and 0 , blood flow measurement was carried out with the animals of each group fixed in a prone position. The only light permitted during the LDPI reading was that emitted by the computer monitor at its lowest setting.

Barrier Disruption, and Evaluation of Barrier Function and Its Recovery Barrier function was evaluated by measuring transepidermal water loss (TEWL) with an electrolytic water analyzer (Tewameter, TM 210 Courage \& Khazaka, Germany), as reported previously by Denda et al. ${ }^{10)}$ Mice were fixed in a prone position on day 0 , and barrier disruption was achieved once by repeated application (10 times) of cellophane tape (LP-18, Nichiban Co., Ltd., Tokyo) on the back skin. TEWL was measured just before and after barrier disruption, and then for $5 \mathrm{~d}$ (from day 0 to day 5).

Microscopic Examination 1) Epidermal Thickness: Epidermal hyperplasia of each animal was assessed according to the method of Haratake et $a .^{25}{ }^{25}$ At the end of the experiment, three $5 \times 10 \mathrm{~mm}$ sections of dorsal skin of the selected mouse were gently removed under ether anesthesia, and immediately fixed with $10 \%$ neutral buffered formalin ( $\mathrm{pH}$ 7.0) for 1 week. The skin specimens were embedded in paraffin, and $6 \mu \mathrm{m}$ sections were cut and stained routinely with hematoxylin and eosin. Epidermal thickness was quantitated on photographs of hematoxylin-and-eosin-stained sections, with a micrometer (0.01 mm, Olympus) and a light microscopic photographic system (ECLIPSE E400, Nikon) fitted with a digital microscope camera (PDMC II, Polaroid) at $\times 200$ magnification. On each section, 200 to 250 points were selected at random, and the thickness of the epidermis was measured with digital image analysis software (Micro Analyzer 1.1, Japan Poladigital Co., Ltd.).

2) Epidermal Proliferative Activity in Vivo: The number of nuclei in the S-phase of the cell cycle in each dorsal skin sample was determined by the modified 5-bromo-2'-deoxyuridine (BrdU) labeling method reported by Nakano et $a l .{ }^{26)}$ Five mice of each group were injected intraperitoneally with BrdU (Sigma, $50 \mathrm{mg} / \mathrm{kg}$ body weight) three times with a $20 \mathrm{~min}$ interval. Each mouse was anesthetized with ether $20 \mathrm{~min}$ later and dorsal skin samples were gently removed and immersed in 20\% sucrose-phosphate-buffered saline $(\mathrm{pH}$ $7.4,4{ }^{\circ} \mathrm{C}$ ). BrdU-immunostaining was performed on $6 \mu \mathrm{m}$ thick frozen sections using the labeled streptavidin-biotinperoxidase method with a rat monoclonal antibody to BrdU, according to Berton et al. ${ }^{27)}$ Finally, each section was counterstained with Mayer's hematoxylin. In this experiment, three $5 \times 10 \mathrm{~mm}$ sections were taken from different parts of each mouse, and BrdU-positive epidermal cells were counted on photographs of BrdU-labeled sections with a micrometer (0.01 mm, Olympus) and a light microscopic photographic system (ECLIPSE E400, Nikon) fitted with a digital microscope camera (PDMC II, Polaroid) at $\times 200$ magnification. For each experiment, at least 1000 epidermal cells were counted and the ratio of labeled nuclei in the epidermis to unlabeled cells was determined.

Evaluation of Corneocyte Maturity According to the method of Grove et al., ${ }^{28)}$ corneocyte size was measured by the use of surface keratinocytes. Material obtained by cellophane tape stripping from the dorsal skin of each mouse was cut into small pieces, placed on slide glass, and stained with $1 \%$ gentian violet $\mathrm{B}$ and $0.5 \%$ brilliant green aqueous solution. On each specimen, 30 corneocytes were selected at random, and the area of the cell surface was measured with digital image analysis software (Nano Hunter NS 2K-pro, Nanosystem Co., Ltd.) at $\times 400$ magnification.

Data Analysis The barrier recovery results were expressed as percent recovery because of variations from day to day in the extent of disruption of the barrier. In each animal the percentage recovery was calculated by applying the following formula: [(TEWL on day 0-TEWL at indicated time $) /($ TEWL on day $0-$ TEWL on day -0$) \times 100]$, where day -0 indicates the time point immediately before tape stripping, and day 0 indicates that immediately after.

Results are expressed as the arithmetic mean \pm S.E. Statistical analysis was conducted using Student's $t$ test or Dunnett's multiple range test with Stat View Software (Version 4.51.1, Berkeley, CA, U.S.A.). $p$ values of less than 0.05 were considered to indicate significant differences.

\section{RESULTS}

Weight Change The body weight gain and food intake per animal of the control ( 5 per cage), isolated ( 1 per cage) and crowded hairless mice $(10,15$ or 20 per cage) are depicted in Table 1. Food intake was reduced significantly by all conditions of crowding, but was slightly increased by isolation. The food intakes of all the crowded hairless mice were similar.

Averaged body weight gain of the isolated mice was slightly lower than that of the untreated control mice on day 0 . In contrast, population-dependent loss of body weight was observed in the crowded animals. There was a significant difference between the control animals and the crowded animals in body weight gain after $7 \mathrm{~d}$ stress. Body weights of the mice exposed to crowded environments of 10 and 20 per cage were decreased by approximately 1.4 and $3.5 \%$ on day 0 , respectively, compared with those of the controls.

In animals exposed to crowded environments for $7 \mathrm{~d}$, there was a modest, but population-dependent change in the weights of the thymus, ovary, kidney and adrenal glands (Table 2). The weights of ovary, thymus and kidney of the most crowded animals (20 per cage) were significantly lower than those of the controls. In contrast, the weight of the 
Table 1. Body Weight Gain and Food Intake in Hairless Mice under Control, Isolated and Crowded Environments and Effect of Carpronium Chloride on Body Weight Gain in Crowded Mice

Exp. I.

\begin{tabular}{|c|c|c|c|c|c|c|}
\hline \multirow{2}{*}{ Group } & \multirow{2}{*}{$\begin{array}{c}\text { Population } \\
\text { density (/cage) }\end{array}$} & \multicolumn{4}{|c|}{ Body weight gain (g) } & \multirow{2}{*}{$\begin{array}{l}\text { Food intake } \\
\text { (g/mouse/d) }\end{array}$} \\
\hline & & -6 & -4 & -2 & 0 (day) & \\
\hline Isolating & $1(n=5)$ & $0.7 \pm 0.2$ & $0.3 \pm 0.2$ & $0.2 \pm 0.4$ & $0.3 \pm 0.4$ & $5.4 \pm 0.4$ \\
\hline Control & $5(n=5)$ & $0.4 \pm 0.1$ & $0.9 \pm 0.4$ & $0.7 \pm 0.2$ & $1.0 \pm 0.3$ & $4.6 \pm 0.1$ \\
\hline Crowding-1 & $10(n=10)$ & $0.1 \pm 0.3$ & $0.3 \pm 0.3$ & $-0.3 \pm 0.2 *$ & $-0.4 \pm 0.3 * *$ & $3.6 \pm 0.1 * * *$ \\
\hline-2 & $15(n=15)$ & $0.0 \pm 0.2$ & $-0.1 \pm 0.2$ & $-0.1 \pm 0.3$ & $-0.5 \pm 0.3 * *$ & $3.8 \pm 0.1 * * *$ \\
\hline-3 & $20(n=20)$ & $-0.1 \pm 0.4$ & $-0.7 \pm 0.4^{*}$ & $-0.9 \pm 0.3^{*}$ & $-0.9 \pm 0.3 * *$ & $3.5 \pm 0.2 * *$ \\
\hline
\end{tabular}

Exp. II.

\begin{tabular}{|c|c|c|c|c|c|c|}
\hline \multirow{2}{*}{ Group } & \multirow{2}{*}{$\begin{array}{c}\text { Dose } \\
(\mathrm{mg} / \mathrm{mouse} / \mathrm{d})\end{array}$} & \multirow{2}{*}{$\begin{array}{c}\text { Population } \\
\text { density (/cage) }\end{array}$} & \multicolumn{4}{|c|}{ Body weight gain (g) } \\
\hline & & & -6 & -4 & -2 & 0 (day) \\
\hline Control & & 5 & $0.2 \pm 0.0$ & $0.7 \pm 0.2 * *$ & $0.8 \pm 0.2 *$ & $1.1 \pm 0.2 *$ \\
\hline Crowding-3 & & 20 & $-0.2 \pm 0.2$ & $-0.9 \pm 0.2$ & $-0.8 \pm 0.2$ & $-0.8 \pm 0.5$ \\
\hline \multirow[t]{2}{*}{ Carpronium chloride } & $(1.0)$ & 20 & $-0.3 \pm 0.1$ & $-0.5 \pm 0.1$ & $-0.6 \pm 0.2$ & $-0.6 \pm 0.1$ \\
\hline & $(5.0)$ & 20 & $-0.4 \pm 0.2$ & $-0.5 \pm 0.2$ & $-0.6 \pm 0.2$ & $-0.8 \pm 0.2$ \\
\hline
\end{tabular}

Exp. I.: Isolated (1 mice/cage) and crowded (10, 15 or 20 mice/cage) environment-induced stress was applied throughout the experimental period for $7 \mathrm{~d}$. Control mice were maintained at 5 mice/cage. Values represent means \pm S.E. $(n=5,10,15$ or 20$)$. * $* *$ and $* * *$ indicate significant differences $(p<0.05,0.01,0.001)$ from the control, respectively. Exp. II.: Crowded (20 mice/cage) environment-induced stress was applied throughout the experimental period for $7 \mathrm{~d}$. Carpronium chloride was applied topically once a day for 8 d. Values represent means \pm S.E. $(n=5)$. * and $* *$ indicate significant differences $(p<0.05,0.01)$ from the crowding- 3 group, respectively.

adrenal glands was significantly increased in the more highly crowded mice (15 and 20 per cage). No significant change was observed in the weights of heart and liver in any group of crowded mice. No apparent change in weight of the above organs was observed in the isolated mice.

The weight reductions of kidney, ovary and thymus and the weight increment of adrenal glands in the mice exposed to the most highly crowded environment became more marked with the passage of time. There was a significant difference in all these changes on day -4 and/or day 0 between the control mice and the most crowded mice.

Hormone Changes Levels of plasma catecholamines and serum corticosterone in the control, isolated and crowded mice are summarized in Table 3. Isolation significantly elevated the level of norepinephrine, but induced no apparent change in the levels of epinephrine, dopamine and corticosterone on day 0 . In contrast, levels of norepinephrine, epinephrine, dopamine and corticosterone were increased significantly by crowding. The changes of levels in epinephrine and dopamine were population-dependent. There was a significant difference in the levels of norepinephrine, epinephrine and dopamine between the control animals and the crowded animals (10, 15 and/or 20 per cage). However, corticosterone was increased markedly to similar levels in all of the crowded animals, compared to the control.

The levels of norepinephrine, epinephrine, dopamine and corticosterone in the control animals were similar throughout the experiment (from day -6 to day 0 ). In contrast, the levels of corticosterone were markedly increased by crowding (20 per cage) during this period. The levels of epinephrine and dopamine were approximately constant from day -6 to day -4 , and then increased markedly on day 0 . One day and three days of stress significantly decreased the level of norepinephrine by $75 \%$, but seven days of stress increased it by $128 \%$.

Changes of Hemocyte Count and Biochemical Profiles in Serum The physiological parameters of blood of the control, isolated and crowded mice are shown in Table 4. There was no apparent change in number of total leukocytes, platelet count and hematocrit in all the groups.

The blood glucose level increased about 1.4-fold, and the serum triglyceride concentration doubled, as compared with those of the control animals on day 0 . These changes were significant. The serum LDH activity was increased significantly by crowding (20 per cage). The increase in total LDH activity was wholly accounted for by increases of $\mathrm{LDH}_{1}$ (12.1\%), $\mathrm{LDH}_{4}(34.9 \%)$ and $\mathrm{LDH}_{5}(50.8 \%)$. In contrast, the averaged serum ALP activity of the crowded animals was significantly decreased.

Skin Surface Lipids Amounts of skin surface lipid were decreased markedly in the most highly crowded mice, with significance compared with the controls (Table 5).

Skin Blood Perfusion The skin blood perfusion in the control, isolated and crowded mice are shown in Table 6. The averaged skin blood perfusion of the control animals was almost constant throughout experiment. Suppression of blood perfusion was elicited in all the crowded animals, and its extent increased in a population-density-dependent fashion. There was a significant difference between the control mice and the more highly crowded mice (15 and 20 per cage) on day -4 or on day 0 . In contrast, skin perfusion was elevated by isolation on day -4 and day 0 . There was a significant difference in this change on day 0 between the isolated mice and the controls.

Skin Barrier Homeostasis To examine the barrier homeostasis in both isolated and crowded animals, TEWLs of all the animals were measured for $6 \mathrm{~d}$, before and immediately after disruption carried out on day 0 and for the following $5 \mathrm{~d}$ (Table 7). The averaged base line TEWL in the mice receiving $7 \mathrm{~d}$ of isolation or crowding on days -0 and 0 (before and immediately after disruption by tape stripping) and on day 1 was almost the same as that of the controls. On the 
Table 2. Weight of Some Organs and Glands in Hairless Mice under Control, Isolated and Crowded Environments and Effect of Carpronium Chloride on Variables in Crowded Mice

Exp. I. (on day 0)

\begin{tabular}{lccccccc}
\hline \hline \multirow{2}{*}{ Group } & \multirow{2}{*}{$\begin{array}{c}\text { Population } \\
\text { density (/cage) }\end{array}$} & \multicolumn{5}{c}{ Organs and glands (mg/100g body weight) } \\
\cline { 3 - 7 } & & Heart & Kidney & Liver & Ovary & \multirow{2}{*}{ Thymus } & Adrenal gland \\
\hline Isolating & 1 & $492.6 \pm 12.7$ & $1574.6 \pm 53.8$ & $6888.9 \pm 59.3 * *$ & $64.3 \pm 3.7$ & $115.0 \pm 13.7$ & $29.3 \pm 0.7$ \\
Control & 5 & $468.0 \pm 10.7$ & $1467.1 \pm 62.8$ & $6257.1 \pm 136.1$ & $63.4 \pm 6.0$ & $113.5 \pm 8.1$ & $27.2 \pm 0.8$ \\
Crowding-1 & 10 & $473.3 \pm 7.4$ & $1342.9 \pm 19.8$ & $6497.1 \pm 63.5$ & $60.6 \pm 3.8$ & $102.8 \pm 10.9$ & $29.7 \pm 0.9$ \\
-2 & 15 & $458.7 \pm 15.3$ & $1319.0 \pm 45.4$ & $6126.7 \pm 170.6$ & $50.4 \pm 4.7$ & $88.5 \pm 1.3$ & $36.1 \pm 0.6 * * *$ \\
\hline
\end{tabular}

Exp. II.

\begin{tabular}{|c|c|c|c|c|c|c|c|c|c|c|}
\hline \multirow{3}{*}{ Group } & \multirow{3}{*}{$\begin{array}{c}\text { Population } \\
\text { density (/cage) }\end{array}$} & \multicolumn{8}{|c|}{ Organs and glands (mg/100 g body weight) } & \\
\hline & & \multicolumn{3}{|c|}{ Heart } & \multicolumn{3}{|c|}{ Kidney } & \multicolumn{3}{|c|}{ Liver } \\
\hline & & -6 & -4 & 0 & -6 & -4 & 0 & -6 & -4 & 0 (day) \\
\hline Control & 5 & $490.4 \pm 8.7$ & $500.6 \pm 14.1$ & $497.4 \pm 15.7$ & $71425.3 \pm 31.2$ & $1582.9 \pm 44.4$ & $1566.7 \pm 49.2$ & $5896.2 \pm 360.8$ & $6614.4 \pm 194.2$ & $5918.2 \pm 214.6$ \\
\hline Crowding-3 & 20 & $522.2 \pm 27.3$ & $494.2 \pm 12.0$ & $479.0 \pm 14.0$ & $01557.0 \pm 68.4$ & $1478.0 \pm 49.7$ & $1424.7 \pm 30.4^{*}$ & $6507.3 \pm 291.4$ & $6165.3 \pm 136.7$ & $5972.7 \pm 110.5$ \\
\hline
\end{tabular}

\begin{tabular}{|c|c|c|c|c|c|c|c|c|c|c|}
\hline \multirow{3}{*}{ Group } & \multirow{3}{*}{$\begin{array}{c}\text { Population } \\
\text { density (/cage) }\end{array}$} & \multicolumn{8}{|c|}{ Organs and glands (mg/100 g body weight) } & \\
\hline & & \multicolumn{3}{|c|}{ Ovary } & \multicolumn{3}{|c|}{ Thymus } & \multicolumn{3}{|c|}{ Adrenal gland } \\
\hline & & -6 & -4 & 0 & -6 & -4 & 0 & -6 & -4 & 0 (day) \\
\hline Control & 5 & $62.6 \pm 8.0$ & $71.6 \pm 9.2$ & $73.1 \pm 4.6$ & $127.4 \pm 10.3$ & $141.3 \pm 10.3$ & $118.9 \pm 5.7$ & $33.5 \pm 3.1$ & $32.9 \pm 5.0$ & $30.9 \pm 1.1$ \\
\hline Crowding-3 & 20 & $68.4 \pm 12.4$ & $65.0 \pm 9.5$ & $50.1 \pm 6.5^{*}$ & $109.0 \pm 12.1$ & $109.6 \pm 7.4^{*}$ & $78.8 \pm 7.0 * *$ & $37.3 \pm 2.9$ & $38.9 \pm 3.0$ & $37.0 \pm 2.1 *$ \\
\hline
\end{tabular}

Exp. III.

\begin{tabular}{|c|c|c|c|c|c|c|c|c|}
\hline \multirow{2}{*}{ Group } & \multirow{2}{*}{$\begin{array}{c}\text { Dose } \\
(\mathrm{mg} / \mathrm{mouse} / \mathrm{d})\end{array}$} & \multirow{2}{*}{$\begin{array}{c}\text { Population } \\
\text { density (/cage) }\end{array}$} & \multicolumn{6}{|c|}{ Organs and glands (mg/100 g body weight) } \\
\hline & & & Heart & Kidney & Liver & Ovary & Thymus & Adrenal gland \\
\hline Control & & 5 & $449.1 \pm 10.8$ & $1322.3 \pm 38.2 *$ & $6531.9 \pm 213.9$ & $85.9 \pm 10.3^{*}$ & $120.6 \pm 11.2 * *$ & $29.0 \pm 1.2 * * *$ \\
\hline Crowding-3 & & 20 & $474.3 \pm 16.0$ & $1204.7 \pm 33.5$ & $6698.0 \pm 92.5$ & $49.9 \pm 1.6$ & $74.4 \pm 5.6$ & $43.4 \pm 1.4$ \\
\hline \multirow[t]{2}{*}{ Carpronium chloride } & $(1.0)$ & 20 & $460.7 \pm 15.4$ & $1273.6 \pm 60.9$ & $6308.6 \pm 239.4$ & $69.0 \pm 7.0$ & $82.3 \pm 8.1$ & $39.3 \pm 3.0$ \\
\hline & $(5.0)$ & 20 & $460.1 \pm 8.5$ & $1246.8 \pm 32.7$ & $6282.5 \pm 122.7 *$ & $76.4 \pm 6.6^{*}$ & $102.8 \pm 9.9 *$ & $42.5 \pm 2.1$ \\
\hline
\end{tabular}

Exp. I and II.: Isolated (1 mice/cage) and crowded (10, 15 or 20 mice/cage) environment-induced stress was applied for 1,3 or $7 \mathrm{~d}($ day $-6,-4$ or 0$)$. Control mice were maintained at 5 mice/cage. Values represent means \pm S.E. $(n=5)$. * ** and $* * *$ indicate significant differences $(p<0.05,0.01,0.001)$ from the control, respectively. Exp. III.: Crowded ( 20 mice/cage) environment-induced stress was applied throughout the experimental period for $7 \mathrm{~d}$. Carpronium chloride was applied topically once a day for $8 \mathrm{~d}$. Values represent means \pm S.E. $(n=5)$. $* * *$ and $* * *$ indicate significant differences $(p<0.05,0.01,0.001)$ from the crowding- 3 group, respectively.

other hand, barrier recovery from day 2 to day 4 after tape stripping was significantly lower in mice exposed to isolated and crowded environments than in the control. The averaged barrier recovery rates of the mice on days 2 and 3 were in the following order, $20<15<10<1<5$ per cage. Five days after disruption (on day 5), there was no significant difference in barrier recovery rates among all the mice.

Macroscopic and Microscopic Findings 1) Macroscopic observation of skin appearance was carried out. No injury or inflammatory sign, such as erythema or edema, was found in any of the groups during the experimental period (data not shown).

2) Hematoxylin-and-eosin-stained dorsal skin sections from the control and crowded mice (20 per cage) are shown in Fig. 2. Epidermal thickness of the control, isolated and crowded mice is summarized in Table 8 . The highly crowded mice (15 and 20 per cage) had a significantly thicker epidermis than the controls on day 0 . Increased dermal cellularity was observed in mice exposed to the most highly crowded environment, compared with that of the controls.

3) BrdU-immunostaining of dorsal skin sections from the control and crowded mice (20 per cage) is depicted in Fig. 3. Proliferative activity of the control, isolated and crowded mice is summarized in Table 8. Whereas twelve S-phase nuclei per 100 total cells were found in the basal epidermal layer of the control mouse, fourteen and twenty-three labeled cells were found in the mice exposed to highly crowded environments (15 and 20 per cage) on day 0 , respectively.

An increase in the proliferative activity of the crowded mice (20 per cage) became more marked with the passage of time. In the lightly crowded animals (10 per cage), there was a slight decrease in proliferative activity, compared with that of the controls. No quantitative differences in proliferative activity were observed between isolated mice and controls.

4) Maturity of corneocytes was examined by quantifying their size in mouse epidermis. Corneocyte sizes of the control, isolated and crowded mice are summarized in Table 8. The corneocyte sizes of the crowded mice were significantly 
Table 4. Hemocyte Counts and Biochemical Profiles in Serum in Hairless Mice under Control, Isolated and Crowded Environments

\begin{tabular}{|c|c|c|c|c|c|c|c|c|}
\hline Group & \multicolumn{2}{|c|}{$\begin{array}{c}\text { Population } \\
\text { density (/cage) }\end{array}$} & \multicolumn{2}{|c|}{$\begin{array}{l}\text { Red blood cells } \\
\qquad\left(\times 10^{4} / \mu \mathrm{l}\right)\end{array}$} & \multicolumn{2}{|c|}{$\begin{array}{l}\text { White blood cells } \\
\qquad\left(\times 10^{2} / \mu \mathrm{l}\right)\end{array}$} & $\begin{array}{l}\text { Platelets } \\
\left(\times 10^{4} / \mu 1\right)\end{array}$ & $\begin{array}{c}\text { Hematocrit } \\
(\%)\end{array}$ \\
\hline Isolating & \multicolumn{2}{|c|}{1} & \multicolumn{2}{|c|}{$926.5 \pm 46.9$} & \multicolumn{2}{|l|}{$46.5 \pm 1.6$} & $6.6 \pm 0.9$ & $45.4 \pm 2.0$ \\
\hline Control & \multicolumn{2}{|c|}{5} & \multicolumn{2}{|c|}{$992.0 \pm 12.0$} & \multicolumn{2}{|l|}{$49.6 \pm 3.9$} & $8.2 \pm 0.3$ & $48.0 \pm 0.3$ \\
\hline Crowding-1 & \multicolumn{2}{|c|}{10} & \multicolumn{2}{|c|}{$952.6 \pm 16.6$} & \multicolumn{2}{|l|}{$56.2 \pm 3.0$} & $9.2 \pm 0.8$ & $47.1 \pm 0.7$ \\
\hline \multirow{2}{*}{$\begin{array}{l}-2 \\
-3\end{array}$} & \multirow{2}{*}{\multicolumn{2}{|c|}{$\begin{array}{l}15 \\
20\end{array}$}} & \multirow{2}{*}{\multicolumn{2}{|c|}{$\begin{array}{l}995.4 \pm 9.8 \\
951.1 \pm 10.9 *\end{array}$}} & \multirow{2}{*}{\multicolumn{2}{|c|}{$\begin{array}{l}47.6 \pm 4.3 \\
49.0 \pm 1.4\end{array}$}} & \multirow{2}{*}{$\begin{array}{l}8.8 \pm 0.5 \\
8.4 \pm 0.5\end{array}$} & $48.1 \pm 0.5$ \\
\hline & & & & & & & & $45.8 \pm 0.5^{*}$ \\
\hline Group & $\begin{array}{c}\text { Population } \\
\text { density (/cage) }\end{array}$ & \multicolumn{2}{|c|}{$\begin{array}{c}\text { Alkaline } \\
\text { phosphatase (IU/l) }\end{array}$} & $\begin{array}{l}\text { Glucose } \\
(\mathrm{mg} / \mathrm{dl})\end{array}$ & \multicolumn{2}{|c|}{$\begin{array}{l}\text { Total cholesterol } \\
\qquad(\mathrm{mg} / \mathrm{dl})\end{array}$} & $\begin{array}{l}\text { HDL-cholesterol } \\
\text { (mg/dl) }\end{array}$ & $\begin{array}{l}\text { Triglyceride } \\
\text { (mg/dl) }\end{array}$ \\
\hline \multirow{2}{*}{$\begin{array}{l}\text { Control } \\
\text { Crowding-3 }\end{array}$} & \multirow{2}{*}{$\begin{array}{r}5 \\
20\end{array}$} & \multirow{2}{*}{\multicolumn{2}{|c|}{$\begin{array}{l}44.9 \pm 1.5 \\
27.7 \pm 1.3 * * *\end{array}$}} & $94.9 \pm 12.0$ & \multirow{2}{*}{\multicolumn{2}{|c|}{$\begin{array}{r}99.5 \pm 3.7 \\
105.1 \pm 3.9\end{array}$}} & \multirow{2}{*}{$\begin{array}{l}56.5 \pm 7.0 \\
51.8 \pm 1.2\end{array}$} & $57.1 \pm 7.4$ \\
\hline & & & & $131.5 \pm 2.2 *$ & & & & $121.6 \pm 9.8^{* *}$ \\
\hline \multirow{2}{*}{ Group } & \multirow{2}{*}{$\begin{array}{c}\text { Population } \\
\text { density (/cage) }\end{array}$} & \multirow{2}{*}{\multicolumn{2}{|c|}{$\begin{array}{l}\text { Total } \mathrm{LDH}^{a)} \\
\quad(\mathrm{IU} / \mathrm{l})\end{array}$}} & \multicolumn{5}{|c|}{ LDH isozyme activity (IU/l) [Relative (\%)] } \\
\hline & & & & $\mathrm{LDH}_{1}$ & $\mathrm{LDH}_{2}$ & $\mathrm{LDH}_{3}$ & $\mathrm{LDH}_{4}$ & $\mathrm{LDH}_{5}$ \\
\hline Control & 5 & & 5.9 & $\begin{array}{c}71.8 \pm 7.2 \\
{[11.7]}\end{array}$ & $\begin{array}{c}63.3 \pm 9.9 \\
{[10.3]}\end{array}$ & $\begin{array}{c}90.3 \pm 9.6 \\
{[14.7]}\end{array}$ & $\begin{array}{c}108.9 \pm 7.7 \\
{[17.7]}\end{array}$ & $\begin{array}{c}279.7 \pm 22.3 \\
{[45.6]}\end{array}$ \\
\hline Crowding-3 & 20 & & $1.5^{*}$ & $\begin{array}{l}96.1 \pm 10.2 \\
{[11.8]}\end{array}$ & $\begin{array}{c}67.4 \pm 14.0 \\
{[8.3]}\end{array}$ & $\begin{array}{c}90.5 \pm 18.8 \\
{[11.1]}\end{array}$ & $\begin{array}{l}178.8 \pm 11.5 \\
{[22.0]}\end{array}$ & $\begin{array}{c}381.5 \pm 12.5 \\
{[46.8]}\end{array}$ \\
\hline
\end{tabular}

Isolated ( 1 mice/cage) and crowded $(10,15$ or 20 mice/cage) environment-induced stress was applied throughout the experimental period for $7 \mathrm{~d}$. Control mice were maintained at 5 mice/cage. Values represent means \pm S.E. $(n=5)$. *, ** and $* * *$ indicate significant differences $(p<0.05,0.01,0.001)$ from the control, respectively. $a)$ LDH: lactate dehydrogenase.

Table 5. Skin Surface Lipid in Hairless Mice under Control and Crowded Environments

\begin{tabular}{lccc}
\hline \hline Group & $\begin{array}{c}\text { Amount of } \\
\text { Population } \\
\text { density }(/ \text { cage })\end{array}$ & skin surface lipid $\left(\mu \mathrm{g} / \mathrm{cm}^{2}\right)$ \\
\cline { 3 - 4 } & & $-7^{a)}$ & $0^{b)}($ day $)$ \\
\hline Control & 5 & $21.3 \pm 0.8$ & $19.9 \pm 2.5$ \\
Crowding-3 & 20 & $20.5 \pm 1.8$ & $5.8 \pm 1.0^{* * *}$ \\
\hline
\end{tabular}

Crowded (20 mice/cage) environment-induced stress was applied throughout the experimental period for $7 \mathrm{~d}$. Control mice were maintained at 5 mice/cage. a) Day -7 : before stress. b) Day 0: after $7 \mathrm{~d}$ of stress. Values represent means \pm S.E. $(n=5)$. $* * *$ indicates a significant difference $(p<0.001)$ from the control.

glands, and in levels of glucocorticoid and catecholamines, in comparison with the control animals. In this crowding model, reduction in skin blood perfusion and rate of barrier recovery and abnormalities of epidermal morphology were observed and became more marked as the population density increased. The cutaneous dysfunctions were well correlated with the reduction in skin blood perfusion.

Stress increases the levels of catecholamines, norepinephrine and epinephrine and glucocorticoid in circulating blood by influencing the autonomic nervous system and the endocrine system. ${ }^{29,30)}$ Tidgren and Hjemdahl reported that levels of peripheral dopamine and arterial blood pressure were increased by mental stress in humans. ${ }^{31)}$ Hans Selye had reported that various stimuli (e.g., excessive heat or cold; forced immobilization and exercise; chemical and physiologic agents) caused hypertrophy of the adrenal glands, atrophy of the thymus and exacerbation of ulcers in the stomach, and these are characteristic changes in response to stress. ${ }^{32,33)}$ Studies of the effects of population density on physiological parameters showed that several stress-related changes, such as inhibition of body weight gain, reduction of food intake, atrophies of thymus, kidney and ovary, and hypertrophy of the adrenal gland are induced in experimental animals (e.g., mice, rats, guinea pig and gilts) exposed to an isolated or overcrowded environment. ${ }^{11,34-39)}$ There are some discrepancies of physiological alterations among the reports, but these seem to be due to methodological differences, such as housing conditions, population density and the experimental duration. Taking these differences into account, we designed experiments to examine the effects of isolation and crowding on female hairless mice.

In hairless mice exposed to a crowded environment (10, 15 or 20 animals per cage) for $7 \mathrm{~d}$, increases in the levels of glucocorticoid and catecholamines, norepinephrine, epinephrine and dopamine in peripheral blood were observed, compared to the untreated controls ( 5 per cage). The crowded mice also developed atrophy of the thymus and ovary and adrenal hypertrophy. Changes in stress hormone levels and negative weight changes of the target organs became more marked with increasing population density. It is well known that increase in the secretion of glucocorticoid causes morphological change of the thymus and adrenal gland. ${ }^{40)}$ In our crowded mice, the weights of these endocrine organs were well correlated with the corticosterone level. In contrast, isolated mice (1 per cage) showed only an apparent increase in the level of norepinephrine. This suggests that isolation mainly activates the sympathetic nervous system, as seen in animals exposed to cold stress. ${ }^{41)}$ These findings demonstrate that crowding is more common as a stressor than social isolation, as the former induced most of the changes reported previously in experimental stress models. ${ }^{11,34-39)}$

As noted above, there are apparent differences in physiological variables between crowded and isolated animals. Our results concerning crowded animals agree with those in previous reports, especially that of Gamallo et al., who recorded significantly higher basal corticosterone levels, lower thymus 
Table 6. Skin Perfusion in Hairless Mice under Control, Isolated and Crowded Environments and Effect of Carpronium Chloride on Decreased Skin Perfusion in Crowded Mice

Exp. I.

\begin{tabular}{|c|c|c|c|c|}
\hline \multirow{2}{*}{ Group } & \multirow{2}{*}{$\begin{array}{c}\text { Population } \\
\text { density (/cage) }\end{array}$} & \multicolumn{3}{|c|}{ Skin perfusion (V) } \\
\hline & & $-7^{a)}$ & -4 & 0 (day) \\
\hline Isolating & 1 & $3.88 \pm 0.04$ & $4.16 \pm 0.07$ & $4.26 \pm 0.07 * *$ \\
\hline Control & 5 & $3.84 \pm 0.05$ & $3.98 \pm 0.05$ & $3.89 \pm 0.06$ \\
\hline Crowding-1 & 10 & $3.87 \pm 0.05$ & $3.78 \pm 0.09$ & $3.67 \pm 0.11$ \\
\hline-2 & 15 & $3.87 \pm 0.05$ & $3.72 \pm 0.04^{* *}$ & $3.70 \pm 0.06$ \\
\hline-3 & 20 & $3.65 \pm 0.06$ & $3.43 \pm 0.38$ & $2.84 \pm 0.21 * *$ \\
\hline
\end{tabular}

Exp. II.

\begin{tabular}{|c|c|c|c|c|c|}
\hline \multirow{2}{*}{ Group } & \multirow{2}{*}{$\begin{array}{c}\text { Dose } \\
\text { (mg/mouse/d) }\end{array}$} & \multirow{2}{*}{$\begin{array}{c}\text { Population } \\
\text { density (/cage) }\end{array}$} & \multicolumn{3}{|c|}{ Skin perfusion (V) } \\
\hline & & & $-7^{a)}$ & -4 & 0 (day) \\
\hline Control & & 5 & $3.95 \pm 0.22$ & $4.20 \pm 0.36$ & $4.00 \pm 0.16^{*}$ \\
\hline Crowding-3 & & 20 & $4.00 \pm 0.09$ & $3.52 \pm 0.24$ & $2.76 \pm 0.06$ \\
\hline \multirow[t]{2}{*}{ Carpronium chloride } & $(1.0)$ & 20 & $4.01 \pm 0.25$ & $4.60 \pm 0.50$ & $4.31 \pm 0.17 *$ \\
\hline & $(5.0)$ & 20 & $3.82 \pm 0.14$ & $4.32 \pm 0.23$ & $4.37 \pm 0.12 * *$ \\
\hline
\end{tabular}

Exp. I.: Isolated (1 mice/cage) and crowded (10, 15 or 20 mice/cage) environment-induced stress was applied for 3 or $7 \mathrm{~d}$ (day -4 or 0$)$. Control mice were maintained at 5 mice/cage. a) Before stress. Values represent means \pm S.E. $(n=10)$. ** indicates a significant difference $(p<0.01)$ from the control. Exp. II.: Crowded $(20$ mice/cage) environment-induced stress was applied throughout the experimental period for $7 \mathrm{~d}$. Carpronium chloride was applied topically once a day for $8 \mathrm{~d}$. Values represent means \pm S.E. $(n=5$ or $6)$. * and $* *$ indicate significant differences $(p<0.05,0.01)$ from the crowding-3 group, respectively.

Table 7. TEWL and Barrier Recovery in Hairless Mice under Control, Isolated and Crowded Environments and Effect of Carpronium Chloride on Delay of Barrier Recovery in Crowded Mice

Exp. I.

\begin{tabular}{|c|c|c|c|c|c|c|c|c|}
\hline \multirow{2}{*}{ Group } & \multirow{2}{*}{$\begin{array}{c}\text { Population } \\
\text { density (/cage) }\end{array}$} & \multicolumn{2}{|c|}{ TEWL $\left(\mathrm{g} / \mathrm{m}^{2} / \mathrm{h}\right)$} & \multicolumn{5}{|c|}{ Barrier recovery $(\%)^{c)}$} \\
\hline & & $-0^{a)}$ & $0^{b)}$ & 1 & 2 & 3 & 4 & 5 (day) \\
\hline Isolating & $1(n=5)$ & $10.6 \pm 1.4$ & $83.3 \pm 1.4$ & $-22.8 \pm 4.4$ & $28.4 \pm 7.2$ & $48.1 \pm 7.4^{*}$ & $70.5 \pm 3.7 *$ & - \\
\hline Control & $5(n=5)$ & $9.3 \pm 0.7$ & $83.2 \pm 1.5$ & $-22.6 \pm 3.4$ & $36.6 \pm 4.9$ & $74.2 \pm 0.9$ & $85.7 \pm 1.4$ & $96.6 \pm 2.1$ \\
\hline Crowding-1 & $10(n=10)$ & $6.7 \pm 0.8$ & $79.2 \pm 1.1$ & $-30.8 \pm 5.9$ & $22.1 \pm 2.7 *$ & $43.5 \pm 9.1^{*}$ & $53.1 \pm 8.4^{*}$ & - \\
\hline-2 & $15(n=15)$ & $7.6 \pm 0.8$ & $81.5 \pm 1.2$ & $-25.3 \pm 0.5$ & $19.9 \pm 4.7 *$ & $27.0 \pm 13.1^{*}$ & $55.9 \pm 4.5^{* *}$ & - \\
\hline-3 & $20(n=20)$ & $10.3 \pm 0.7$ & $76.3 \pm 0.5$ & $-35.9 \pm 3.6$ & $3.2 \pm 6.0 *$ & $20.5 \pm 11.9 * *$ & $55.0 \pm 9.6^{*}$ & $82.9 \pm 7.0$ \\
\hline
\end{tabular}

Exp. II.

\begin{tabular}{|c|c|c|c|c|c|c|c|c|}
\hline \multirow{2}{*}{ Group } & \multirow{2}{*}{$\begin{array}{c}\text { Dose } \\
\text { (mg/mouse/d) }\end{array}$} & \multirow{2}{*}{$\begin{array}{c}\text { Population } \\
\text { density (/cage) }\end{array}$} & \multicolumn{2}{|c|}{ TEWL $\left(\mathrm{g} / \mathrm{m}^{2} / \mathrm{h}\right)$} & \multicolumn{4}{|c|}{ Barrier recovery $(\%)^{c)}$} \\
\hline & & & $-0^{a)}$ & $0^{b)}$ & 1 & 2 & 3 & 4 (day) \\
\hline Control & & 5 & $10.9 \pm 1.0$ & $60.9 \pm 0.8$ & $-59.0 \pm 4.9$ & $4.6 \pm 11.1^{* *}$ & $48.8 \pm 4.9^{* *}$ & $71.6 \pm 3.1 *$ \\
\hline Crowding-3 & & 20 & $11.7 \pm 1.8$ & $61.4 \pm 1.6$ & $-69.4 \pm 9.8$ & $-51.5 \pm 9.9$ & $12.0 \pm 5.8$ & $31.3 \pm 13.6$ \\
\hline Carpronium chloride & $(1.0)$ & 20 & $10.8 \pm 0.4$ & $63.8 \pm 0.8$ & $-56.6 \pm 11.7$ & $-16.4 \pm 8.3^{*}$ & $43.8 \pm 9.6^{*}$ & $62.2 \pm 6.2$ \\
\hline & $(5.0)$ & 20 & $9.5 \pm 0.8$ & $61.0 \pm 1.0$ & $-80.7 \pm 8.2$ & $-19.2 \pm 4.1^{*}$ & $26.6 \pm 9.8$ & $55.0 \pm 10.8$ \\
\hline
\end{tabular}

Exp. I.: Isolated (1 mice/cage) and crowded (10, 15 or 20 mice/cage) environment-induced stress was applied throughout the experimental period for $13 \mathrm{~d}$. Control mice were maintained at 5 mice/cage. $7 \mathrm{~d}$ after the stress exposure (day 0 ), barrier disruption was achieved by tape stripping. TEWL was measured just before and after tape stripping, and then for $5 \mathrm{~d}$. a) Day -0 : before tape stripping. b) Day 0 : immediately after tape stripping. $c$ ) Percentage barrier recovery was calculated by means of the formula described in methods. Values represent means \pm S.E. $(n=5,10,15$ or 20$)$. $*$ and $* *$ indicate significant differences $(p<0.05,0.01)$ from the control, respectively. - : not examined. Exp. II.: Crowded $(20 \mathrm{mice} / \mathrm{cage})$ environment-induced stress was applied throughout the experimental period for $7 \mathrm{~d}$. Carpronium chloride was applied topically once a day for $8 \mathrm{~d}$ before tape stripping. Values represent means \pm S.E. $(n=5$ or 6$)$. $*$ and $* *$ indicate significant differences $(p<0.05,0.01)$ from the crowding-3 group, respectively.

weight and adrenal hypertrophy in animals under crowded conditions. $^{34)}$ With regard to the effect of isolation, our results suggests that isolated animals appear more frightened from the neuroendocrine point of view, since the level of norepinephrine was markedly elevated. This difference could be attributed to different mechanisms implicated in the two different social situations. While crowding could be considered as a chronic stress pattern, isolation, in contrast, may represent a lack of social stimuli necessary to modulate adaptative responses of animals to new situations. However, further study on isolation is needed to establish its stressful nature in detail.

The stress responses were time-dependent. ${ }^{32)}$ In this study, mice exposed to a crowded environment showed a decrease in norepinephrine level on short exposure (on day -6 to day -4 ), but an increase on longer exposure (on day 0 ), compared with control animals. The levels of epinephrine and dopamine increased in a time-dependent manner. On the 
A)

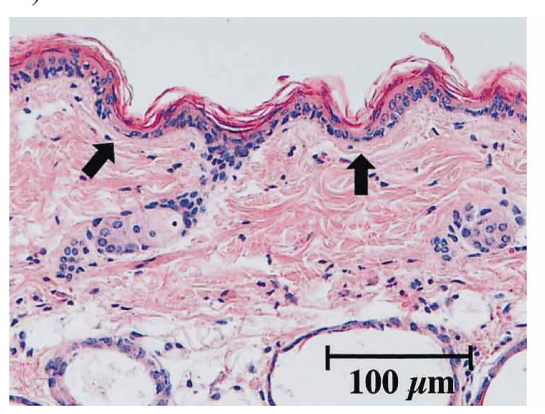

B)

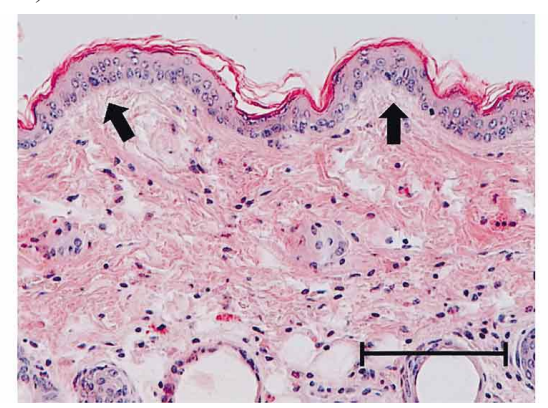

C)

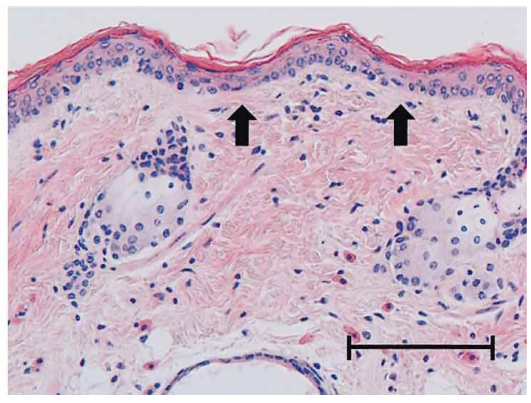

Fig. 2. Hematoxylin and Eosin Staining of Hairless Mice Dorsal Skin Sections

Dorsal skin sections of control mouse (A), crowded mouse $(20$ mice/cage $)(B)$ and crowded mouse treated with carpronium chloride $(1.0$ mg/mouse/d) $(\mathrm{C})$ on day $0(\times 200)$. Bars: $100 \mu \mathrm{m}$.

A)

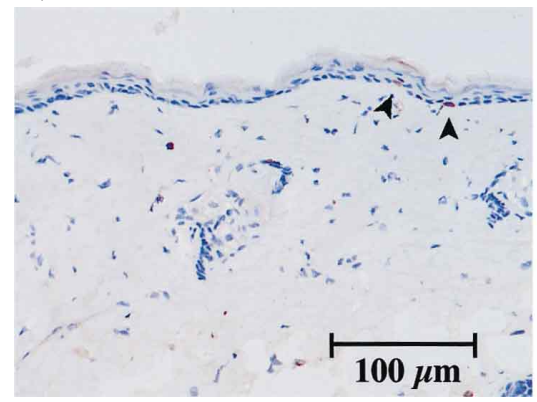

B)

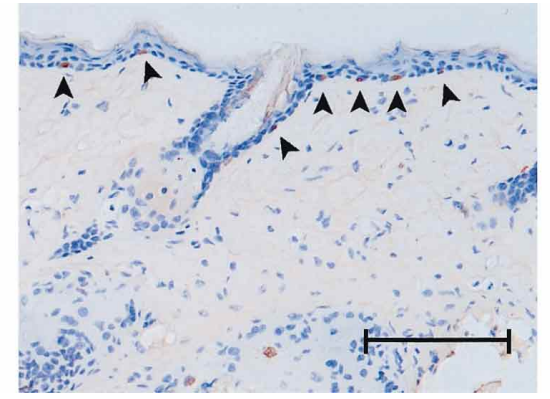

C)

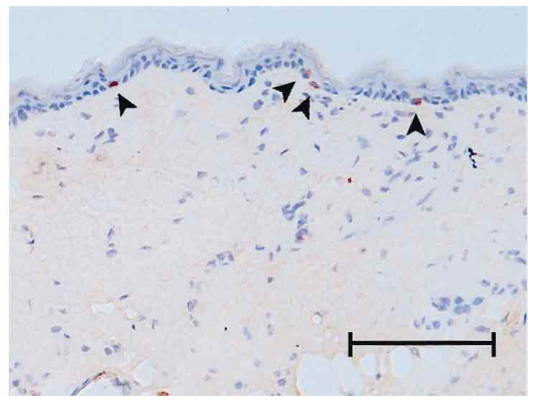

Fig. 3. Immunostaining of Hairless Mice Dorsal Skin Sections with Anti-BrdU

Dorsal skin sections of control mouse (A), crowded mouse (20 mice/cage) (B) and crowded mouse treated with carpronium chloride (1.0 mg/mouse/d) $(\mathrm{C})$ on day 0 ( $\times 200)$. Arrowheads: BrdU-labeled basal keratinocytes. Bars: $100 \mu \mathrm{m}$.

other hand, during the experimental period, crowding markedly elevated the corticosterone level. The increase in corticosterone levels reached a plateau when the population density was more than twice that of the control group. This is a first time that levels of corticosterone and catecholamines have been found to be changed by an overcrowded environment. Thus, it appears that crowding influences the hypothalamic-pituitary-adrenocortical axis, sympatho-adrenomedullary system, and sympathetic nervous system. It is known that, when animals are exposed to stress, firstly the levels of catecholamines and/or corticosterone are rapidly increased and then further changes are caused by both metabolic systems and negative feedback mechanisms. Catechol-O-methyltransferase (COMT) metabolizes norepinephrine. It was reported that, in the immobilization-induced stressed rat, the activity of COMT is increased by a first immobilization, but decreased by repeating the procedure. ${ }^{42}$ ) The time-dependent changes in COMT activity may be one reason why norepinephrine levels change throughout the experimental period.

As typical stress-related changes were found in the hairless mouse exposed to overcrowded environments, we concluded that this is an appropriate model to examine the effects of stress on the whole body, including skin function and skin blood perfusion.

Several reports have shown that stress reduces blood flow. For example, Shapiro et al. reported that the reduction in the prefrontal cortex was greater in subjects with high hostility. ${ }^{43)}$ Stress led to a marked decrease of blood flow velocity in microvessels in water immersion and restraint models. ${ }^{44)}$ It is conceivable that deficits in the blood circulatory system in the dermis have a considerable effect on homeostasis of the skin. However, the determinants of stress-induced coronary constriction and flow velocity responses are not well understood. In our study, the rate of skin blood perfusion became lower with increasing population density or with more prolonged exposure to a crowded environment in hairless mice. This result suggests that the degree of population density and the length of the exposure period determine the dose of "stress," at least as regards skin blood perfusion. In contrast, isolation significantly increased skin perfusion. To our knowledge, this is the first report that skin blood perfusion is affected by stress due to overcrowding or isolation.

The changes in levels of catecholamines and corticosterone were well correlated with blood perfusion in crowded hairless mice, as described above. Various stressful events may increase the vascular resistance of peripheral blood vessels and elevate blood pressure. ${ }^{31,43-45)}$ Such a reaction may be generated by excess norepinephrine and epinephrine, which are released mainly from sympathetic nerve endings and the adrenal medulla following excitation of the sympathetic nervous system, and affect adrenergic receptors in the target organs. Norepinephrine and epinephrine function to constrict the vascular smooth muscle of the skin capillary vessels through the $\alpha_{1}$-adrenoceptor. ${ }^{46)}$ It is also reported that the vasoconstrictive effect of catecholamine was increased by excess glucocorticoid. ${ }^{47}$ ) These findings suggest that the reduction of skin perfusion in crowded mice is induced mainly by the constrictive effect of increased catecholamines and 
Table 8. Epidermal Cell Proliferative Activity, Thickness and Corneocyte Size in Hairless Mice under Control, Isolated and Crowded Environments and Effect of Carpronium Chloride on Epidermal Differentiation Disorder and Hyperplasia in Crowded Mice

Exp. I. (on day 0)

\begin{tabular}{rcccc}
\hline \hline \multicolumn{1}{c}{ Group } & Population density $(/$ cage $)$ & Epidermal thickness $(\mu \mathrm{m})$ & Proliferative activity $(\%)$ & Corneocyte size $\left(\mu \mathrm{m}^{2}\right)$ \\
\hline Isolating & 1 & $20.8 \pm 0.4$ & $11.5 \pm 0.9$ & $718.0 \pm 40.6$ \\
Control & 5 & $19.5 \pm 0.7$ & $11.5 \pm 1.1$ & $748.5 \pm 21.9$ \\
Crowding-1 & 10 & $19.4 \pm 1.2$ & $7.8 \pm 0.6$ & $652.0 \pm 23.8^{*}$ \\
-2 & 15 & $22.3 \pm 0.7^{* *}$ & $14.1 \pm 1.2$ & $595.1 \pm 18.5^{* * *}$ \\
-3 & 20 & $24.2 \pm 0.6^{* * *}$ & $22.8 \pm 2.8^{* *}$ & $550.3 \pm 21.3^{* * *}$ \\
\hline
\end{tabular}

Exp. II.

\begin{tabular}{cccccc}
\hline \hline \multirow{2}{*}{ Measure } & & \multicolumn{3}{c}{ Crowding-3 (20 mice/cage) } \\
\cline { 3 - 6 } & $-7^{a)}($ day $)$ & -6 & -4 & -2 & $0($ day $)$ \\
\hline Proliferative activity $(\%)$ & $7.4 \pm 0.5$ & $6.7 \pm 0.4$ & $6.5 \pm 0.4$ & $10.5 \pm 1.0^{*}$ & $18.7 \pm 2.8^{* *}$ \\
Corneocyte size $\left(\mu \mathrm{m}^{2}\right)$ & $775.5 \pm 11.9$ & $745.2 \pm 47.2$ & $637.4 \pm 15.1^{* * *}$ & $506.0 \pm 17.3^{* * *}$ & $549.7 \pm 23.1^{* * *}$ \\
\hline
\end{tabular}

Exp. III

\begin{tabular}{lccccc}
\hline \hline \multirow{2}{*}{ Group } & \multirow{2}{*}{$\begin{array}{c}\text { Population } \\
\text { density (/cage) }\end{array}$} & \multicolumn{3}{c}{ Corneocyte size $\left(\mu \mathrm{m}^{2}\right)$} \\
\cline { 3 - 6 } & & 0 & 2 & 3 & $4($ day) \\
\hline Control & 5 & $713.8 \pm 11.0$ & $530.8 \pm 24.6^{\# \#}$ & $687.0 \pm 40.8$ & $696.5 \pm 58.2$ \\
Crowding-3 & 20 & $568.3 \pm 12.4^{* * *}$ & $477.0 \pm 27.9^{\#}$ & $593.1 \pm 52.5$ & $537.6 \pm 39.0$ \\
\hline
\end{tabular}

Exp. IV.

\begin{tabular}{lccccccc}
\hline \hline \multirow{2}{*}{ Group } & $\begin{array}{c}\text { Dose } \\
\text { (mg/mouse/d) }\end{array}$ & $\begin{array}{c}\text { Population } \\
\text { density }(/ \text { cage })\end{array}$ & $\begin{array}{c}\text { Epidermal } \\
\text { thickness }(\mu \mathrm{m})\end{array}$ & $\begin{array}{c}\text { Proliferative } \\
\text { activity }(\%)\end{array}$ & \multicolumn{3}{c}{ Corneocyte size $\left(\mu \mathrm{m}^{2}\right)$} \\
\cline { 6 - 8 } & & 5 & $17.3 \pm 0.8^{*}$ & $7.4 \pm 0.9^{* *}$ & $724.3 \pm 30.1^{* * *}$ & $535.2 \pm 49.3$ & $578.8 \pm 15.3^{*}$ \\
Control & & 20 & $22.5 \pm 0.7$ & $15.7 \pm 2.0$ & $544.5 \pm 16.4$ & $495.0 \pm 30.0$ & $466.0 \pm 35.5$ \\
Crowding-3 & $(1.0)$ & 20 & $19.7 \pm 0.6$ & $11.7 \pm 0.9$ & $560.1 \pm 6.2$ & $551.7 \pm 21.6$ & $520.2 \pm 22.4$ \\
Carpronium chloride & $(5.0)$ & 20 & - & - & $603.0 \pm 27.6$ & $475.8 \pm 23.2$ & $500.0 \pm 38.2$
\end{tabular}

Exp. I.: Isolated (1 mice/cage) and crowded (10, 15 or 20 mice/cage) environment-induced stress was applied throughout the experimental period for $7 \mathrm{~d}$. Control mice were maintained at 5 mice/cage. Values represent means \pm S.E. $(n=5)$. $* * *$ and $* * *$ indicate significant differences $(p<0.05,0.01,0.001)$ from the control, respectively. Exp. II.: Crowded (20 mice/cage) environment-induced stress was applied for $1,3,5$ or $7 \mathrm{~d}$ (day $-6,-4,-2$ or 0$)$. $a$ ) Day -7 : before stress. Values represent means \pm S.E. ( $n=5$ ). *, ** and $* * *$ indicate significant differences $(p<0.05,0.01,0.001)$ from day -7 , respectively. Exp. III.: Crowded $(20$ mice/cage) environment-induced stress was applied throughout the experimental period for $12 \mathrm{~d}$. Control mice were maintained at 5 mice/cage. $7 \mathrm{~d}$ after the stress exposure (day 0 ), barrier disruption was achieved by tape stripping. Values represent

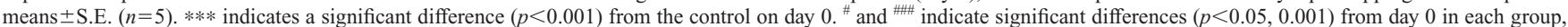
respectively. Exp. IV.: Crowded ( 20 mice/cage) environment-induced stress was applied throughout the experimental period for $7 \mathrm{~d}$. Carpronium chloride was applied topically once a day for $8 \mathrm{~d}$. Values represent means \pm S.E. $(n=5)$. *, ** and $* * *$ indicate significant differences $(p<0.05,0.01,0.001)$ from the crowding-3 group, respectively. - : not examined.

corticosterone on skin capillaries. With regard to atrophy of kidney and ovary in crowded animals, since both $\alpha$ - and $\beta$ adrenoceptors exist in the microcirculatory system of these organs, the changes in these organs may occur via similar mechanisms. However, the reason why skin blood perfusion increased in the isolated mice is unclear.

Measurement of LDH activity and electrophoresis of isozymes have been used as tools for investigating cellular injury in organs and tissues. ${ }^{22,48)}$ Increase of LDH activity and decrease of ALP activity were induced by crowding in the guinea pig. ${ }^{35)}$ In our investigation, crowding caused a significant increase in the total LDH activity, which was characterized by increases in specific LDH isozymes, especially $\mathrm{LDH}_{4}$ and $\mathrm{LDH}_{5}$. Crowding also decreased ALP. As noted above, weight reductions of kidney, ovary and thymus and suppression of skin blood perfusion were observed in mice exposed to a crowded environment. Based on the reported LDH isozyme distributions in organs, skeletal muscle, erythrocytes and endothelium of mice and rat, $\mathrm{LDH}_{4}$ and $\mathrm{LDH}_{5}$ are especially rich in endothelium and kidney. ${ }^{48,49)}$ Vascular endothelial cells lining blood vessels are multifunctional cells playing a key role in the local control of vascular tone, and it has been suggested that the gradual disappearance of ALP activity is related to the development of functional impairment of endothelium. ${ }^{50}$ These findings suggest that crowding increases the microvascular resistance, resulting in an increase in LDH activity due to dysfunction of the endothelium. However, further investigation is needed.

Topical application of carpronium chloride prevented the reduction of blood perfusion in the skin, and atrophy of kidney, thymus and ovary in highly crowded hairless mice. It also decreased the levels of norepinephrine and epinephrine, but had no effect on the level of dopamine. It has been reported that carpronium chloride shows good skin permeability and is a cholinergic agent. It has a continuous vasodilating effect on the skin blood vessels, suppressing the release of norepinephrine from the vascular nerves, and is resistant to cholinesterase. ${ }^{51)}$ As muscarine-like acetylcholine receptors exist in the microvasculature, carpronium chloride can directly bind to this receptor, like acetylcholine, in the micro- 
circulation system and thus functions to reduce microvasculature constriction induced by stressful stimuli. This may be the reason why it prevented the reduction of skin blood perfusion in our crowding model. Atrophy of kidney and ovary may be partially prevented by this agent in a similar way, but the mechanism of its effect on thymus is not clear.

Next, we examined the effect of isolation or overcrowding on skin homeostasis in hairless mice. During the experimental period, no injury, erythema or edema was seen macroscopically in the back skin of the experimental animals of any group in this study. This supports the view that our experimental conditions are suitable for studying the effects of stress, as injury and friction are excluded as physical factors. In the crowded mice, the levels of skin surface lipids were significantly lower than those of the control animals, but the TEWLs of both groups were similar. Tsuchiya et al. reported that immobilization-induced stress lowered testosterone secretion and consequently the testosterone level in the skin, resulting in decreased sebaceous lipogenesis in the skin. ${ }^{9)}$ Our result suggests that overcrowding lowers secretion of testosterone from the adrenal gland. Recently, a cutaneous biological study indicated that overcrowding stress induced an increase of TEWL in electronically clipped dorsal skin of BALB/c mice. ${ }^{11)}$ The living area per animal in that study was three times that in our experiment (20 per cage). Skin dysfunction in crowded mice is increased population-dependently, as described below. This distinct difference of TEWL could have been due to the difference of population density in the two studies.

Clinically, the association of stressful stimuli with inflammatory skin diseases, such as atopic dermatitis and psoriasis, which are characterized by epidermal hyperproliferation and cutaneous inflammation, has long been recognized. ${ }^{52-54)} \mathrm{In}$ jury by tape stripping, acetone treatment, or UV irradiation of mammalian skin induces a variety of acute responses, including erythema, hyperplasia, an increase in the number of inflammatory cells, and hyperproliferation. ${ }^{55)}$ The form and arrangement of surface corneocytes reflect cellular organization within the epidermis and are a good index of proliferation and differentiation-induction potency. ${ }^{28)}$ Morphological changes found by the use of histochemical and immunohistochemical techniques and analysis of tape-stripped corneocytes in the skin of highly crowded hairless mice (15 and 20 per cage) included epidermal hyperplasia, epidermal hyperproliferation, increased number of dermal cells, and epidermal differentiation disorder. In contrast, these abnormalities were not detected in the isolated animals. Epidermal hyperplasia, epidermal hyperproliferation and epidermal differentiation disorder became more marked with increase of both population density and exposure time. This demonstrates that the crowding of hairless mice causes psychological stress that has an adverse effect on skin condition. This is first report to show that skin morphological abnormalities, such as hyperplasia, epidermal hyperproliferation and differentiation disorder of corneocytes, are induced by overcrowding. Further study on this skin morphology is on-going, because it is still unclear how the inflammatory reaction is induced by crowding-induced stress.

Previous reports demonstrated that overcrowding stress induced a delay of skin recovery. ${ }^{10)}$ Bullough et al. reported that sex hormone stimulates the proliferation of ker- atinocytes, ${ }^{56)}$ but glucocorticoids and catecholamines are inhibitory in vitro. ${ }^{57-59)}$ We found that both crowding and isolation delayed barrier recovery after barrier disruption in the hairless mice. This delay became more marked with increasing population density. Differentiation disorder of corneocytes in the crowded mice remained after the barrier disruption. Delay of skin barrier recovery in the crowded mice was well correlated with the changes in epidermal proliferative activity, differential ability, and skin blood perfusion. Skin turnover follows the sequence: basal cells proliferate, then differentiate stepwise to prickel cells, granular cells and corneocytes, and finally corneocytes are shed from the surface. Crowding appears to cause immaturity of corneocytes in the hairless mice by inducing epidermal hyperproliferation, and epidermal differentiation disorder, which could delay barrier recovery. Skin turnover could be impaired by the reduction of skin blood perfusion due to crowding, owing to inadequate supply of nutrients and chemical transmitters, including socalled stress hormones, in peripheral microvessels in the skin. While topical application of carpronium chloride significantly reduced the delay of the skin barrier recovery and inhibited the reduction of skin blood perfusion, it only slightly improved epidermal hyperproliferation and epidermal differentiation disorder. These facts suggest that skin perfusion is strongly related to barrier recovery in the crowded animals. In isolated animals, delay of barrier recovery may be caused by an excess of norepinephrine, which inhibits epidermal proliferation.

Crowding decreases food intake and body weight gain in rats. ${ }^{11,35,36)}$ This has been attributed to stress reaction to crowding. However, we found that three different levels of crowding caused a population-dependent reduction of body weight gain, but essentially the same degree of decrease of food intake in all groups. It has also been found that feeding behavior, which is controlled by both glucose-sensitive and glucoreceptive nerves, is suppressed by elevated blood glucose $^{60,61)}$ Crowding could suppress feeding behavior by elevating blood glucose level. The release of catabolic hormones as a consequence of stress reaction to crowding could also contribute to the inhibition of body weight gain.

In conclusion, we demonstrated that crowding activates the hypothalamic-pituitary-adrenocortical axis, sympathoadrenomedullary system and sympathetic nervous system in the same manner as psychological stress. Crowding reduces skin blood perfusion, delays barrier recovery, and induces epidermal hyperplasia, epidermal hyperproliferation, and epidermal differentiation disorder in the hairless mouse. Delayed skin barrier recovery is well correlated with an increase in catecholamines and a reduction of blood perfusion in the skin of overcrowded animals. A parasympathetic nerve stimulator, carpronium chloride, improved skin morphology, skin barrier recovery and skin blood perfusion in overcrowded mice. These results support our hypothesis that blood perfusion plays an important role in the regulation of skin homeostasis. Isolation also delayed barrier recovery, though it increased skin blood perfusion. Further study is necessary to clarify the mechanisms of skin dysfunction caused by crowding and isolation. The crowded environment-induced stress model presented here could be useful in studying the relationship between stress and cutaneous dysfunction, and in screening tests to find effective agents to treat skin distur- 
bances due to mental stress.

\section{REFERENCES}

1) DiMario F. J., Jr., Burleson J. A., Pediatr. Neurol., 26, 130-133 (2002).

2) De Luna M. L., Barquin M. A., Casas J. G., Sidelsky S., Pediatr. Dermatol., 12, 159-163 (1995).

3) Schurer N. Y., Elias P. M., Adv. Lipid Res., 24, 27-56 (1991).

4) Adler G., Gattaz W. F., Biol. Psychiatry, 34, 687—689 (1993).

5) Feingold K. R., Williams M. L., Pillai S., Menon G. K., Halloran B. P., Bikle D. D., Elias P. M., Biochim. Biophys. Acta, 930, 193-200 (1987).

6) Yoshida M., Hirotsu S., Nakahara M., Uchiwa H., Tomita Y., J. Invest. Dermatol., 118, 255-260 (2002).

7) Cooper E. L., "Stress, Immunity, and Aging," Marcel Dekker, New York, 1984.

8) Anand P., Springall D. R., Blank M. A., Sellu D., Polak J. M., Bloom S. R., Br. J. Dermatol., 124, 547-549 (1991).

9) Tsuchiya T., Horii I., Psychoneuroendocrinology, 20, 221-230 (1995).

10) Denda M., Tsuchiya T., Hosoi J., Koyama J., Br. J. Dermatol., 138, $780-785$ (1998)

11) Aioi A., Okuda M., Matsui M., Tonogaito H., Hamada K., J. Dermatol. Sci., 25, 189-197 (2001).

12) Ghiadoni L., Donald A. E., Cropley M., Mullen M. J., Oakley G., Taylor M., O'Connor G., Betteridge J., Klein N., Steptoe A., Deanfield J. E., Circulation, 102, 2473-2478 (2000).

13) Algotsson A., Nordberg A., Winblad B., J. Gerontol.; Med. Sci., 50A, M121-M127 (1995).

14) Sommer A., Veraart J., Neumann M., Kessels A., Acta Derm. Venereol., 78, 15-18 (1998).

15) Troilius A., Wardell K., Bornmyr S., Nilsson G. E., Ljunggren B., Acta Derm. Venereol., 72, 6-10 (1992).

16) Boranic M., Poljak-Blazi M., Exp. Hematol., 11, 873-877 (1983).

17) Capel I. D., Jenner M., Pinnock M. H., Dorrell H. M., Williams D. C., Environ. Res., 23, 162-169 (1980).

18) Csermely P., Penzes I., Toth S., Experimentia, 51, 976-979 (1995).

19) Gomez-Sanchez C., Murry B. A., Kem D. C., Kaplan N. M., Endocrinology, 96, 796-798 (1975).

20) Tsuchiya T., Horii I., Psychoneuroendocrinology, 21, 111-117 (1996).

21) Maruta K., Fujita K., Ito S., Nagatsu T., Clin. Chem., 30, 1271-1273 (1984).

22) Schultze A. E., Gunaga K. P., Wagner J. G., Tox. Appl. Pharmocology, 126, 301-310 (1994).

23) Dikstein S., Zlotogorski A., Avriel E., Katz M., Bioeng. Skin, 3, 197207 (1987).

24) Bjarnason B., Flosadottir E., Fischer T., Contact Dermatitis, 41, 211217 (1999).

25) Haratake A., Uchida Y., Schmuth M., Tanno O., Yasuda R., Epstein J. H., Elias P. M., Holleran W. M., J. Invest. Dermatol., 108, 769-775 (1997).

26) Nakano R., Tsuyama S., Murata F., J. Dermatol. Sci., 14, 54-62 (1997).

27) Berton T. R., Mitchell D. L., Fischer S. M., J. Invest. Dermatol., 109,
340-347 (1997).

28) Grove G. L., Kligman A. M., "Stratum Corneum," ed. by Marks R., Plewig G., Springer-Verlag, Berlin Heidelberg, 1983, pp. 191-195.

29) Vollmer R. R., Baruchin A., Kolibal-Pegher S. S., Corey S. P., Stricker E. M., Kaplan B. B., Am. J. Physiol., 263, R716-R721 (1992).

30) Aguilera G., Front. Neuroendocrinol., 15, 321-350 (1994).

31) Tidgren B. O., Hjemdahl P., Am. J. Physiol., 257, F682-F689 (1989).

32) Selye H., Nature (London), 138, 32 (1936).

33) Selye H., J. Clin. Endocrinol., 6, 117-230 (1946).

34) Gamallo A., Villanua A., Trancho G., Fraile A., Physiol. Behav., 36, 217-221 (1986).

35) Kaminaga H., Shinomiya T., Jpn. J. Dermatol., 107, 615-622 (1997).

36) Armario A., Castellanos J. M., Balasch J., Neuroendocrinology, 39, $330-333$ (1984).

37) Armario A., Ortiz R., Balasch J., Physiol. Behav., 32, 35-37 (1984).

38) Rahe C. H., Jungst S. B., Marple D. N., Kuhlers D. L., J. Anim. Sci., 65, 439-444 (1987).

39) Garzonis P., Manta S., Papadopoulos J. S., Annales $d$ Anatomie Pathologique, 25, 295-306 (1980).

40) Hu Y., Gursoy E., Cardounel A., Kalimi M., Endocr. J., 13, 123-129 (2000).

41) Graham T. E., Sathasivam P., MacNaughton K. W., J. Appl. Physiol., 70, 2052-2058 (1991)

42) Kvetnansky R., Torda T., Jahnova E., Saleh N., Endocrinol. Exp., 9, 79-86 (1975).

43) Shapiro P. A., Sloan R. P., Bagiella E., Kuhl J. P., Anjilvel S., Mann J. J., J. Psychosom. Res., 48, 485-491 (2000).

44) Filaretova L. P., Levkovich I. I., Mal'tsev N. A., Fiziol Zhurn Imeni I. M. Sechenova, 82, 71-78 (1996)

45) Frank S. M., Cattaneo C. G., Wieneke-Brady M. B., El-Rahmany H., Gupta N., Lima J. A., Clin. Sci., 102, 119-125 (2002).

46) Janig W., "Human Physiology," 2nd ed., Springer-Verlag, 1989, pp. $333-370$

47) Grunfeld J. P., Eloy L., Presse. Med., 16, 1365-1367 (1987)

48) Ishida H., Nakayasu H., Nukaya H., Tsuji K., Biol. Pharm. Bull., 22, 822 - 827 (1999).

49) Nayar R., Boswell R. S., Metz K. R., Lattimore D., Sen S., Cytobios., 59, 69-77 (1989)

50) Kato S., Nakamura H., Acta Neuropathol., 73, 220-226 (1987).

51) Takahashi H., Koshino C., Ikeda O., Jpn. J. Physiol., 12, 97 (1962).

52) Schmid-Ott G., Jaeger B., Meyer S., Stephan E., Kapp A., Werfel T., J. Allergy Clin. Immunol., 108, 455- 462 (2001).

53) Buske-Kirschbaum A., Geiben A., Hellhammer D., Psychother. Psychosom., 70, 6-16 (2001).

54) Seville R. H., Br. J. Dermatol., 97, 297-302 (1977).

55) Denda M., Wood L. C., Emami S., Calhoun C., Brown B. E., Elias P. M., Feingold K. R., Arch. Dermatol. Res., 288, 230-238 (1996).

56) Bullough W. S., Van Oordt G. J., Acta Endocrinol., 4, 291-305 (1950).

57) Bullough W. S., Laurence E. B., Proc. R. Soc. Lond., 154, 540-556 (1961).

58) Bullough W. S., Laurence E. B., Exp. Cell Res., 43, 343-350 (1966).

59) Bullough W. S., Laurence E. B., Cell Tissue Kinet., 1, 5-10 (1968).

60) Oomura Y., Ono T., Ooyama H., Wayner M. J., Nature (London), 222, 282-284 (1969).

61) Oomura Y., Ooyama H., Sugimori M., Nakamura T., Yamada Y., Nature (London), 247, 284-286 (1974). 